\title{
TEKNIK BERCERITA UNTUK MENINGKATKAN KEMAMPUAN MOTORIK HALUS PADA ANAK USIA 4-6 TAHUN DI TKN KINTELAN SEMARANG
}

\author{
Yohanes Eko Anugrahanto $^{1^{*}}$, Natalia Ratna Yulianti ${ }^{1}$, Wati Windayani ${ }^{2}$ \\ ${ }^{1}$ STIKES St. Elisabeth Semarang \\ ${ }^{2}$ RS. St. Elisabeth Semarang \\ yohaneseko2210@gmail.com
}

\begin{abstract}
Abstrak
Teknik bercerita merupakan aktivitas penyampaian cerita secara lisan yang dapat memberikan pengalaman menyenangkan dalam sebuah aktivitas pembelajaran. Namun saat ini teknik bercerita belum terlalu umum diterapkan dalam menstimulasi perkembangan motorik halus anak. Teknik bercerita juga belum pernah diterapkan di TKN Kintelan Semarang dalam menstimulasi motorik halus anak. Padahal dalam pelaksanaannya teknik bercerita dapat disisipkan aktivitas atau permainan yang dapat merangsang perkembangan motorik halus anak. Penelitian ini bertujuan untuk mengetahui pengaruh teknik bercerita terhadap peningkatan motorik halus anak usia $4-6$ tahun di TKN Kintelan Semarang. Jenis penelitian ini adalah kuantitatif yang menggunakan desain pre-eksperimental dengan pendekatan pretestposttest one group design. Sampel berjumlah 34 responden yang memenuhi kriteria inklusi dan eksklusi dengan teknik pengambilan sampel purposive sampling. Uji normalitas data menggunakan uji Shapiro-wilk, dan uji statistik menggunakan uji Wilcoxon. Hasil uji Wilcoxon didapatkan p-value delay pretest-posttest adalah 0,000 dan p-value caution pretest-posttest adalah 0,000 yang berarti $\mathrm{p}<0,05$ yang memiliki makna bahwa terdapat pengaruh teknik bercerita terhadap peningkatan motorik halus anak usia $4-6$ tahun di TKN Kintelan Semarang.
\end{abstract}

Kata kunci: Teknik Bercerita; Peningkatan Motorik Halus; Anak usia 4 - 6 tahun

\begin{abstract}
The storytelling technique is an oral story-telling activity that provides a fun experience in a learning activity. This might help teachers to improve child development. However, the story-telling technique is not common to stimulate fine motor development among children. The storytelling technique has not been applied in TKN Kintelan Semarang in stimulating fine motor of children. This study aimed to measure the effect of the storytelling technique towards fine motor development among children aged 4 - 6 years old in TKN Kintelan Semarang. This study applied quantitative research with pre-experimental design with pretest-posttest one group design. Sample amounted to 34 children who have fulfilled the inclusion and exclusion criteria by purposive sampling. Data normality was tested using Shapiro-wilk test. The effect of the techniques was tested using Wilcoxon Test. Wilcoxon test resulted value delay pretest-posttest was 0.000 and pvalue caution pretest-posttest is 0.000 which means $p<0,05$ which means that there was an effect of storytelling toward fine motor improvement in children aged $4-6$ years old in TKN Kintelan Semarang
\end{abstract}

Keywords: storytelling, fine motor skill, children aged 4 - 6 years old 


\section{Pendahuluan}

Anak dalam perkembangannya memerlukan beberapa keterampilan perawatan diri (self-care) untuk mempertahankan hidup, kesehatan, dan kesejahteraan. Keterampilan motorik halus dapat digunakan anak dalam mencapai kemandiriannya dimana anak dapat melakukan kegiatan bagi diri mereka sendiri (Asmadi, 2008; Muhlisin \& Irdawati, 2010). Perkembangan anak usia $4-6$ tahun diharapkan anak dapat melakukan kegiatan secara mandiri dengan menggunakan tangannya untuk bermain, makan sendiri, minum dari cangkir dengan bantuan, menggunakan sendok dengan bantuan, dan makan dengan jari (Hurlock, 2010). Perkembangan motorik halus yang optimal akan membantu anak dalam memenuhi kebutuhan anak secara mandiri terkait dengan penggunaan dan pengaturan otot-otot jari tangan. Gangguan perkembangan motorik halus yang dialami oleh anak dapat diatasi dengan pemberian stimulasi atau rangsangan, sehingga dalam penerimaan informasi terkait motorik halus dapat dipacu secara optimal sesuai dengan rentang usia anak (Santrock, 2007; Hurlock, 2010; Sulistyawati, 2014).

Stimulasi pertumbuhan dan perkembangan anak dapat dilakukan dengan berbagai cara dalam membantu peningkatan kemampuan gerak kasar, kemampuan gerak halus, kemampuan berbicara, kemampuan sosial dan kemandirian (Sulistyawati, 2014). Stimulasi yang diberikan kepada anak dapat berupa penglihatan, pendengaran, dan perabaan (Santrock, 2007).

Stimulasi dapat dilakukan dengan cara memberikan cerita yang baik untuk anak. Pemberian stimulasi bercerita dapat memberikan rangsangan pada anak lewat penglihatan dan pendengaran yang diberikan saat bercerita. Anak dapat merefleksikan stimulus yang dia terima berupa penggunaan kata-kata, gerakan dan gambar yang dipakai pembaca dalam menggambarkan situasi dari cerita yang diberikan.

Teknik bercerita mempunyai keunggulan dalam memberikan stimulasi perkembangan motorik halus pada anak. Dalam pemberian stimulasi teknik bercerita dapat diberikan dengan berbagai cara sehingga anak dapat tertarik mengikuti alur cerita yang diberikan. Gambar dan gerakan yang disajikan oleh peneliti akan menarik minat anak. Tidak hanya menarik minat dengan menggunakan gambar dan gerakan, teknik bercerita juga bisa disisipkan aktivitas terkait kemampuan motorik halus anak seperti penggunaan pensil untuk menggambar berbagai bentuk (manusia, persegi, persegi panjang, lingkaran, dan garis menyilang), membandingkan garis panjang dan pendek serta menyusun menara dari balok (Santrock, 2007; Abdurrahman, 2012). Teknik bercerita dapat memberikan rangsangan perseptual dimana anak mempersepsikan stimulasi yang diterima melalui indranya (Abdurrahman, 2012).

Stimulasi teknik bercerita pada saat ini belum terlalu umum dan masih sedikit penelitian yang dilakukan dalam mendukung perkembangan motorik halus anak. Stimulasi teknik bercerita lebih sering digunakan sebagai stimulasi perkembangan bahasa dan kemampuan mendengar pada anak. Hal itu disebabkan pemberian stimulasi bercerita difokuskan pada susunan kata- kata dan bahasa serta pesan-pesan yang diberikan pembaca dalam sebuah cerita (Musfiroh, 2009). Penelitian yang telah dilakukan dengan menggunakan dongeng pada anak pra sekolah di PAUD/KB Bunda Aini didapatkan hasil ada pengaruh mendengarkan dongeng terhadap kemampuan berbahasa anak prasekolah (Azkiya, 2016). Penelitian lain yang dilakukan dengan menggunakan stimulasi bercerita pada anak di Ibadan, Nigeria didapatkan hasil ada pengaruh pemberian cerita terhadap kemampuan mendengar anak (Odoulowu, 2014).

Perkembangan motorik halus anak memiliki fungsi yang sangat berguna bagi kemandirian anak. Keterampilan dalam menggunakan otot jari-jari tangan membantu anak memenuhi kebutuhannya sehari-hari. Namun tidak semua anak mengalami perkembangan motorik halus secara optimal, hal ini dapat menghambat anak dalam kemandiriannya. Stimulasi yang diberikan diharapkan dapat memberikan dorongan dan membantu anak dalam menerima informasi yang berguna bagi keterampilan motorik 
halusnya.

Stimulasi motorik halus yang diberikan pada anak dapat dilakukan dengan pemberian teknik bercerita. Namun teknik bercerita ini belum umum digunakan dalam menstimulasi perkembangan motorik halus anak. Studi pendahuluan yang telah dilakukan terdapat 38 dari 62 anak di TKN Kintelan Semarang mengalami suspect keterlambatan dalam perkembangan motorik halus berdasarkan pengukuran menggunakan Denver II dan mereka belum pernah mendapatkan stimulasi bercerita dalam meningkatkan perkembangan motorik halus anak. Penelitian ini bertujuan untuk mengetahui pengaruh teknik bercerita terhadap perkembangan motorik halus pada murid di TKN Kintelan Semarang.

\section{Metode}

Desain yang digunakan dalam penelitian ini adalah eksperimental yang menerapkan teknik bercerita dengan pendekatan pre test-post test one group design. Pengukuran perkembangan motorik halus sebelum dan sesudah diberikan perlakuan dengan menggunakan lembar penilaian Denver II. Penelitian ini dilakukan di TKN Kintelan Semarang. Populasi pada penelitian ini adalah semua anak berusia 4 sampai 6 tahun yang diduga mengalami keterlambatan perkembangan motorik halus di TKN Kintelan Semarang berdasarkan test Denver II dengan jumlah 38 anak. Sampel ditentukan dengan teknik purposive sampling dengan criteria inklusi: 1) mendapatkan persetujuan dari guru 2) mengikuti stimulasi bercerita selama 4 hari berturut-turut dan criteria ekslusi sebagai berikut: 1) Anak yang mempunyai keterbelakangan mental; 2) Anak yang memiliki cacat fisik; 3) Anak yang sedang sakit pada tangan. Sampel yang didapatkan sebanyak 34 anak.

Pelaksanaan penelitian ini melibatkan 7 orang asisten untuk mengukur perkembangan anak menggunakan Denver II sebelum dan sesudah diberikan stimulasi bercerita. Stimulasi ini dilakukan sebanyak 4 kali dalam 4 hari selama 23 menit. Tema cerita pada masing-masing pertemuan berbeda. Stimulasi teknik bercerita dilaksanakan di aula TKN Kintelan Semarang. Semua anak dikumpulkan pada satu tempat dan waktu yang sama dalam dilakukannya teknik bercerita. Di sela-sela cerita, anak diminta untuk melakukan aktivitas motorik halus seperti menggambar, menyusun balok, menunjuk gambar, dan mewarnai gambar sesuai dengan alur dan tema cerita.

\section{Hasil}

Karakteristik Responden Berdasarkan Jenis Kelamin di TKN Kintelan Semarang $(n=34)$

Tabel 1. Distribusi frekuensi jenis kelamin responden di TKN Kintelan Semarang

\begin{tabular}{lll} 
& $(\mathrm{n}=34)$ & \\
\hline Jenis Kelamin & $\mathrm{n}$ & $\%$ \\
\hline Laki-laki & 22 & 64,7 \\
Perempuan & 12 & 35,3 \\
\hline Total & 34 & 100 \\
\hline
\end{tabular}

Tabel 1 menunjukan bahwa data jumlah responden laki-laki sebanyak 22 anak $(64,7 \%)$ lebih banyak dibandingkan dengan jumlah responden perempuan sebanyak 12 anak $(35,3 \%)$.

\section{Karakteristik Responden Berdasarkan Usia di TKN Kintelan Semarang $(n=34)$}

Tabel 2. Distribusi frekuensi usia responden di TKN Kintelan Semarang $(n=34)$

\begin{tabular}{lcl}
\hline Usia & $\mathrm{n}$ & $\%$ \\
\hline 4 Tahun -4 tahun 11 bulan & 18 & 52,9 \\
$5-6$ tahun & 16 & 47,1 \\
\hline Total & 34 & 100 \\
\hline
\end{tabular}

Tabel 2 menunjukan bahwa responden yang berusia $4-4$ tahun 11 bulan sebanyak 18 anak $(52,9 \%)$ lebih banyak dibandingkan responden dengan usia $5-6$ tahun sebanyak 16 anak $(47,1 \%)$. 


\section{Perubahan Jumlah Delay Sebelum Dan Sesudah Diberikan Perlakuan Teknik Bercerita.}

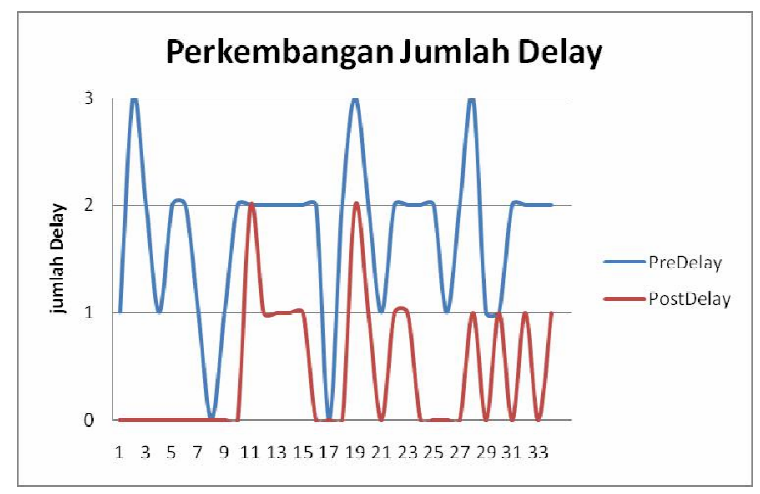

Gambar 1. Perubahan jumlah delay sebelum dan sesudah perlakuan teknik bercerita.

Tabel 3. Perubahan jumlah delay sebelum dan sesudah perlakuan teknik bercerita

\begin{tabular}{cccc}
\multicolumn{4}{c}{$(\mathrm{n}=34)$} \\
\hline Jumlah & \multicolumn{2}{c}{ Pretest } \\
\cline { 2 - 4 } delay & $\mathrm{n}$ & $\%$ & $\mathrm{n}$ \\
\hline 0 & 2 & 5,9 & 21 \\
1 & 9 & 26,5 & 11 \\
2 & 20 & 58,8 & 2 \\
3 & 3 & 8,8 & - \\
\hline Total & 34 & 100 & 34 \\
\hline
\end{tabular}

Jumlah delay sebelum diberi perlakuan yang tertinggi adalah 3 sebanyak 3 anak $(8,8)$ dan delay terendah adalah 0 sebanyak 2 anak (5,9\%). Responden dengan jumlah delay 1 sebanyak 9 anak $(26,5 \%)$ dan responden dengan jumlah delay 2 sebanyak 20 anak $(58,8 \%)$. Jumlah delay tertinggi sesudah diberikan perlakuan adalah 2 sebanyak 2 anak $(5,9 \%)$ dan terendah adalah 0 sebanyak 21 anak $(61,8 \%)$ dan responden dengan jumlah delay 1 sebanyak 11 anak $(32,4 \%)$.

\section{Perubahan Jumlah Caution Sebelum Dan Sesudah Diberikan Perlakuan Teknik Bercerita.}

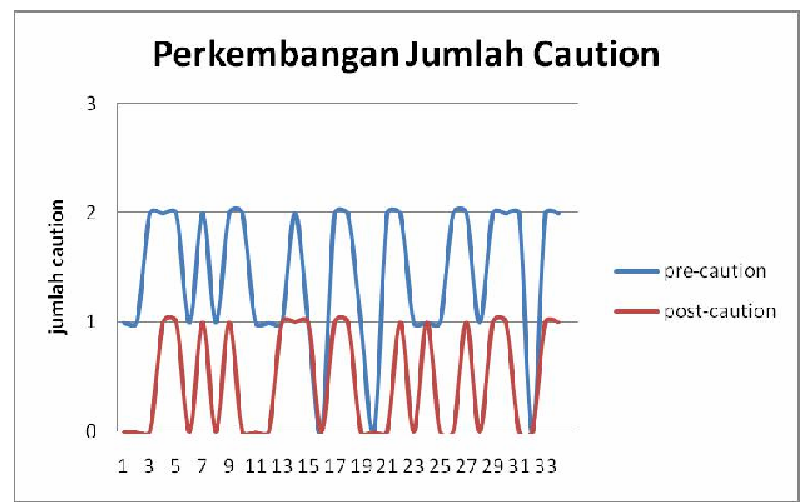

Gambar 2. Perubahan jumlah caution sebelum dan sesudah perlakuan teknik bercerita

Tabel 4. Perubahan jumlah caution sebelum dan sesudah perlakuan teknik bercerita

Posttest $\quad(\mathrm{n}=34)$


Data delay sebelum dan sesudah diberi perlakuan dilakukan uji normalitas dengan menggunakan uji Shapiro -Wilk $(\mathrm{n}=34)$. Hasil nilai signifikansi delay sebelum perlakuan yaitu $\mathrm{p}=0,000(\mathrm{p}<0,05)$ dan sesudah perlakuan yaitu $\mathrm{p}=0,000$ $(p<0,05)$. Data caution sebelum dan sesudah diberi perlakuan juga dilakukan uji normalitas menggunakan Shapiro-Wilk. Hasil nilai signifikansi caution sebelum perlakuan yaitu $\mathrm{p}=0,000(\mathrm{p}<0,05)$ dan nilai signifikansi caution setelah perlakuan yaitu $\mathrm{p}=0,000(\mathrm{p}<0,05)$. Didapatkan hasil distribusi data delay sebelum dan sesudah dan distribusi data caution sebelum dan sesudah yaitu $\mathrm{p}<0,05$ sehingga data tidak terdistribusi normal karena data tersebut tidak terdistribusi normal maka dilakukan transformsi data terlebih dahulu, kemudian kembali dilakukan uji normalitas data Shapiro-Wilk. Hasil uji normalitas yaitu nilai signifikansi delay sebelum perlakuan $\mathrm{p}=0,000(\mathrm{p}<0,05)$ dan nilai delay sesudah perlakuan $p=0,000(p<0,05)$. Hasil nilai signifikansi caution sebelum yaitu $\mathrm{p}=$ 0,000 dan nilai caution sesudah $\mathrm{p}=0,000$ $(\mathrm{p}<0,05)$ karena $\mathrm{p}<0,05$ maka distribusi data tetap tidak normal sehingga digunakan uji alternatif yaitu uji Wilcoxon. Uji alternatif Wilcoxon p-value $=0.000$ dimana $\mathrm{p}<0.05$ yang berarti $\mathrm{H} 0$ ditolak dan H1 diterima sehingga ada pengaruh teknik bercerita terhadap peningkatan motorik halus anak.

\section{Pembahasan}

Hasil uji alternatif Wilcoxon didapatkan $\mathrm{p}$-value $=0.000$ dimana $\mathrm{p}<0.05$ yang berarti $\mathrm{H} 0$ ditolak dan $\mathrm{H} 1$ diterima sehingga ada pengaruh teknik bercerita terhadap peningkatan motorik halus anak. Hal ini sesuai dengan penelitian yang dilakukan oleh Hidayat pada tahun 2009, pemberian cerita dongeng dapat berpengaruh pada perkembangan seseorang. Hasil tersebut juga sesuai dengan penelitian yang dilakukan oleh Azkiya pada tahun 2016 di PAUD / KB Bunda Aini dan Oduolowu pada tahun 2014 di Ibadan, Nigeria bahwa dengan pemberian dongeng dapat merangsang perkembangan pada anak. Pada penelitian ini didapatkan data jumlah delay dan caution tertinggi sesudah dilakukan teknik bercerita mengalami penurunan. Hal ini sesuai dengan penelitian Kartyasih pada tahun 2015 di TK Negeri Pembina Batursari bahwa ada pengaruh pemberian stimulasi terhadap penurunan jumlah delay dan jumlah caution anak (Kartyasih, 2015). Adanya pengaruh teknik bercerita terhadap perkembangan motorik halus anak yaitu 30 responden mengalami penurunan jumlah delay dan 16 responden mengalami penurunan jumlah caution dikarenakan saat anak mulai mengikuti kegiatan bercerita, anak menerima stimulasi melalui berbagai indra (Hurlock, 2010). Stimulasi visual yang diterima disalurkan oleh sistem syaraf optik menuju pada korteks visual. Dalam korteks visual pesan-pesan yang diterima akan diproses oleh sel-sel sederhana, sel-sel kompleks, dan sel-sel hiperkompleks kemudian akan diintrepetasikan sebagai persepsi visual bentuk-bentuk, garis-garis dan pergerakan tertentu (Ling \& Catling, 2012) Dengan persepsi visual tersebut anak akan termotivasi untuk bergerak dari apa yang mereka persepsikan mengenai bentuk-bentuk visual yang ada (Santrock, 2007). Pergerakan itu akan membawa impuls dari susunan sistem syaraf pusat mengirim sinyal dari neuron, sinyal yang dikirim menuju neuron motorik bagian bawah melalui sinaps. Sinyal yang sampai pada neuron motorik bagian bawah akan meningkatkan perkembangan organorgan reseptor dan sel-sel motorik sehingga merangsang perkembangan motorik halus (Hurlock, 2010). Peningkatan kemampuan motorik halus pada anak akan terlihat dengan dilakukannya tes Denver II. Pada penelitian ini juga terdapat anak yang tidak mengalami perubahan pada jumlah delay dan jumlah caution, hal ini disebabkan anak tidak serius saat diberikan teknik bercerita dan anak sudah mulai lelah karena sebelum diberikan perlakuan anak sudah mengikuti kegiatan belajar dimana konsentrasi anak mulai menurun. Konsentrasi yang menurun tersebut menyebabkan anak tidak fokus terhadap stimulasi yang diberikan (Santrock 2007).

Diantara 34 responden didapatkan data anak laki-laki lebih banyak mengalami penurunan jumlah delay. Hal ini dapat disebabkan pada waktu diberikan stimulasi anak laki-laki lebih aktif dan antusias jika dibandingkan dengan anak 
perempuan yang lebih pasif saat diberikan stimulasi. Sehingga dengan pemberian stimulasi teknik bercerita dengan aktivitas motorik halus, keterampilan penggunaan jari-jari tangan anak laki-laki lebih terlatih dibandingkan dengan anak perempuan yang dalam stimulasi lebih pasif. Hal tersebut juga dapat diakibatkan oleh perpedaan konsep diri pada anak laki- laki dan perempuan. Konsep diri pada anak tersebut akan memicu kepada anak perempuan kurang percaya diri sehingga anak perempuan lebih pasif dalam mengikuti stimulasi (Santrock, 2007).

Usia merupakan salah satu faktor yang dapat mempengaruhi proses perkembangan motorik halus anak. Responden pada penelitian ini adalah anak yang berusia $4-6$ tahun. Pada penelitian ini didapatkan hasil bahwa responden usia $4-4$ tahun lebih 11 bulan lebih banyak dibandingkan dengan usia 5 - 6 tahun. Pada penurunan jumlah caution didapatkan pula bahwa usia $5-6$ tahun lebih banyak dibandingkan dengan responden dengan usia $4-4$ tahun lebih 11 bulan. Hal ini dapat disebabkan pada responden usia 5-6 tahun penggunaan jari tangan sudah semakin meningkat sehingga anak lebih terampil untuk melakukan aktivitasnya dimana tangan digunakan sebagai alat.

Pengukuran perkembangan motorik halus dengan menggunakan Denver II didapatkan pada usia $4-4$ tahun 11 bulan responden tidak bisa meniru gambar lingkaran sebanyak 17 responden, menggambar orang 3 bagian sebanyak 14 responden, meniru garis menyilang 11 responden, meniru garis vertikal sebanyak 8 responden dan menyusun balok sebanyak 5 responden. Pada usia $5-6$ tahun didapatkan responden tidak bisa menggambar orang 6 bagian sebanyak 12 responden, menirukan gambar persegi sebanyak 12 responden, menggambar orang 3 bagian sebanyak 8 responden, meniru gambar persegi panjang sebanyak 8 responden, menirukan gambar lingkaran sebanyak 5 responden dan menirukan gambar garis menyilang sebanyak 5 responden. Setelah dilakukannya stimulasi teknik bercerita pada usia $4-4$ tahun 11 bulan responden mengalami penurunan skor gagal yang sangat pesat dalam menirukan gambar lingkaran sebanyak 13 responden. Hal yang sama dialami pada responden dengan usia $5-6$ tahun pada item menirukan gambar lingkaran mengalami penurunan skor gagal sebanyak 5 responden dimana semua responden usia 5 - 6 tahun setelah diberikan stimulasi teknik bercerita dapat menirukan gambar lingkaran. Pada item menirukan gambar persegi responden juga mengalami penurunan skor gagal yang pesat sebanyak 10 responden. Pada umumnya semua item mengalami penurunan jumlah skor gagal dimana penurunan yang paling signifikan adalah menirukan gambar lingkaran dan menirukan gambar persegi. Hal ini dapat disebabkan pada saat diberikannya stimulasi teknik bercerita anak tidak hanya mendengarkan cerita saja tetapi anak juga melakukan aktivitas motorik halus terkait dengan item-item yang terdapat pana lembar penilaian Denver II. Responden dapat terbiasa untuk melakukan aktivitas motorik halus tersebut sehingga keterampilan pengkoordinasian jari-jari tangan mengalami peningkatan (Ling \& Catling, 2012).

Meningkatnya kemampuan motorik halus anak dapat mendorong anak dalam memenuhi kebutuhannya secara mandiri seperti bermain, menggunakan pensil untuk menggambar dan menulis, menggunakan sendok untuk makan, memegang cangkir untuk minum dan sebagainya. Kemampuan anak dalam mempertahankan hidup, kesehatan dan kesejahteraan merupakan bagian dari kemandirian. Kemandirian anak yang terganggu akan menyebabkan ketergantungan anak terhadap orang tua atau orang terdekat dalam menjalankan aktivitasnya terkait dengan kegiatan bermain, makan, minum, menulis dan sebagainya. Menurut teori self-care yang dipaparkan oleh Orem setiap kegiatan dan 
tindakan keperawatan yang dilakukan sebagai upaya memacu kemampuan seseorang dalam melakukan perawatan diri sesuai dengan tahap tumbuh kembangnya (Muhlisin \& Irdawati, 2010). Keterampilan motorik halus dapat digunakan anak dalam mencapai kemandiriannya dimana anak dapat melakukan kegiatan bagi diri mereka sendiri terkait penggunaan jari-jari tangan (Asmadi, 2008; Muhlisin \& Irdawati, 2010). Hal ini sesuai dengan penelitian yang dilakukan di SDLB AKW Kumara Surabaya dimana anak memerlukan kemandirian dalam melakukan berbagai aktivitas terkait dengan perkembangan otot-otot dan sendi-sendi pada tangan (Yuemi, 2015). Kemandirian anak yang terganggu akan mempengaruhi keterampilan dalam melakukan aktivitasnya. Anak akan mengalami ketidakpercayaan diri dalam menyelesaikan suatu masalah yang muncul dalam aktivitasnya sehari-hari. Ketidakpercayaan diri tersebut akan menyebabkan ketergantungan anak pada orang lain, dengan begitu keterampilan anak tidak berkembang secara optimal dan dapat menyebabkan gangguan perkembangan motorik halus terkait dengan penggunaan otot-otot jari tangan (Muhlisin \& Irdawati, 2010).

Adanya penurunan jumlah delay dan jumlah caution sebelum dan sesudah dilakukannya teknik bercerita, dapat disimpulkan bahwa stimulasi teknik bercerita tidak hanya digunakan dalam menstimulasi perkembangan bahasa dan kemampuan mendengarkan anak saja tetapi teknik bercerita juga efektif diberikan kepada anak dalam menstimulasi perkembangan motorik halus anak. Dengan memberikan stimulasi teknik bercerita secara teratur, perkembangan motorik halus pada anak akan berkembang secara maksimal sehingga anak dapat beraktivitas secara mandiri dalam memenuhi kebutuhan seperti makan, minum dan menggunakan alat tulis.

\section{Keterbatasan Penelitian}

Peneliti kurang mempertimbangkan jadwal ekstrakurikuler di TKN Kintelan Semarang sehingga sebagian anak yang tidak mengikuti ekstrakurikuler harus menunggu. Hal tersebut mengakibatkan anak lelah dan kurang kooperatif dalam mengikuti kegiatan stimulasi teknik bercerita.

\section{Simpulan dan Saran}

Stimulasi dengan teknik bercerita terbukti berpengaruh terhadap peningkatan kemapmpuan motorik halus pada anak usia $4-6$ tahun. Pada penelitian selanjutnya diharapkan dapat mengukur dan mempertimbangkan faktor-faktor lain yang dapat mempengaruhi perkembangan motorik halus anak.

\section{Ucapan Terima Kasih}

Peneliti mengucapkan terima kasih kepada Bapak St. Suhadi, Sp. Kep. Kom atas saran praktis untuk strategi pelaksanaan penelitian ini.

\section{Daftar Pustaka}

Abdurrahman M. Anak Berkesulitan Belajar. Jakarta: Rineka Cipta; 2012.

Asmadi. Konsep Dasar Keperawatan. Jakarta: EGC; 2008.

Azkiya NR. Pengaruh Mendengarkan Dongeng Terhadap Kemampuan Bahasa pada Anak Prasekolah. Jurnal Ilmu Psikologi Terapan. 2016;4(2):123-39. Available from : http://ejournal.umm.ac.id [Accessed 2th June 2017].

Hidayat A. Pengaruh Dongeng dalam Masa Kanak-Kanak Terhadap Perkembangan Seseorang. Jurnal Study Gender dan Anak. 2019;2(4):1-7. Available from: http://download.portalgaruda.org [accessed 10th July 2017] 
Hurlock EB. Perkembangan Anak. Jakarta: Erlangga; 2010.

Kartyasih E. Pengaruh Pendampingan Terhadap Perkembangan Motorik Kasar Dengan Melompat Satu Kaki Pada Anak Usia 4 - 5 Tahun di Tk Negeri Pembina Batursari. Jurnal Ilmu Keperawatan dan Kebidanan. 2015;2(2):52-59. Available from : http://download.portalgaruda.org.

[Accessed 16th Sept 2017]

Ling J, Catling J. Psikologi Kognitif. Jakarta: Erlangga; 2012.

Muhlisin A, Irdawati. Teori Self Care Dari Orem dan Pendekatan Dalam Praktek Keperawatan. Berita Ilmu Keperawatan ISSN 1979-2697. 2010;2(2):97-100. Available from : http://journals.ums.ac.id [Accessed 1th August 2017].

Musfiroh T. Menumbuhkan kembangkanBaca-Tulis Anak Usia Dini. Gramedia Widiasarana Indonesia; 2009.

Santrock. Perkembangan Anak. Jakarta: Erlangga; 2007.

Oduolowu E. Effect of Storytelling on Listening Skills of Primary One Pupil in Ibadan North Local Government Area of Oyo State, Nigeria. International Journal of Humanities and Social Science. 2014;4(9):100-7. Available from : http://www.ijhssnet.com [Accessed 7th July 2017].

Sulistyawati A. Deteksi Tumbuh Kembang Anak. Jakarta: Selemba Medika; 2014.

Yuemi CP, Mundakir. Terapi okupasi: diorama gambar terhadap kemampuan motorik halus pada anak retardasi mental ringan. The Sun. 2015;2(2):54-60. Available from : http://fik.um-surabaya.ac.id. [Accessed 16th Sept 2017 